\title{
A relief-specific model of the ice age on the basis of uplift-controlled glacier areas in Tibet and the corresponding albedo increase as well as their positive climatological feedback by means of the global radiation geometry
}

\author{
Matthias Kuhle* \\ Geographisches Institut der Universität Göttingen, Goldschmidtstraße 5, 37077 Göttingen, Germany
}

\begin{abstract}
The onset of the ice age era at $\sim 2.75 \mathrm{Ma} B P$ and its increasing intensity from $\sim 1 \mathrm{Ma}$ BP

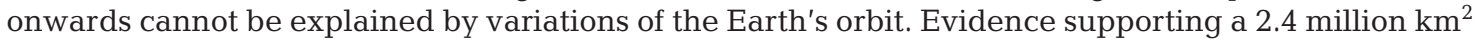
ice sheet on the Tibetan plateau during the Last Glacial Maximum has led to the hypothesis that the resulting albedo-induced heat loss in the Earth's atmosphere may have triggered global ice ages. Recent data obtained from marine and terrestrial sediment records now confirm the climaticecological impact of a Tibetan glaciation; they also show that the development of Tibet's ice sheet was synchronous with the onset and intensification of global ice ages.
\end{abstract}

KEY WORDS: Ice ages · Tibetan ice sheet · Quaternary climate

Resale or republication not permitted without written consent of the publisher

\section{INTRODUCTION}

The $\delta^{18} \mathrm{O}$ records of planktonic foraminifera (Shackleton et al. 1988, Morley \& Dworetzky 1991, Tiedemann et al. 1994) have shown that the Quaternary ice age began at about $2.75 \mathrm{Ma} \mathrm{BP}$; from $1 \mathrm{Ma} \mathrm{BP}$ onwards, its intensity (ice volume) and the length of its glacial phases approximately doubled (Fig. 1b). It is now recognized that the explanation of these events cannot be found in variations of the Earth's orbital parameters (Berger et al. 1999). Insolation variations (Fig. 1a) - which have displayed the same patterns for tens of millions of years (Berger \& Loutre 1991) account for the waxing and waning of global ice volumes to a limited degree (Hays et al. 1976), but to explain why ice ages occur at all and why they increased so rapidly during the past $1 \mathrm{Ma}$, we must look for a completely different, terrestrial cause.

In recent years, the continuous decline in levels of the greenhouse gas $\mathrm{CO}_{2}$ in the atmosphere and a con-

*E-mail: mkuhle@gwdg.de comitant global cooling have been considered to be the most likely cause (Broecker 1995, Ruddiman et al. 1997). Computer simulations by Berger et al. (1999) show that, to trigger ice ages in this way, atmospheric $\mathrm{CO}_{2}$ must have decreased from more than 320 parts per million by volume (ppmv) to 200 ppmv during the past $3 \mathrm{Ma}$. However, the latest alkenone-based $\mathrm{CO}_{2}$ estimates (Pagani et al. 1999, Pearson \& Palmer 1999) have shown that, in spite of high temperatures, $\mathrm{CO}_{2}$ levels during the Tertiary were by no means highersometimes even lower-than the preindustrial value of 270 ppmv in postglacial times or $>300$ ppmv during the Eem Interglacial (Fischer et al. 1999). So there is still no evidence for a decrease in atmospheric $\mathrm{CO}_{2}$ concentration since the Tertiary/Quaternary transition that may have caused temperatures to fall. Furthermore, the fine-scale records of the GRIP ice core confirm that during the last 3 glaciations the $\mathrm{CO}_{2}$ values lagged climatic change by as much as several thousands of years (Fischer et al. 1999, Mudelsee 2001). This reverses the previously accepted causal nexus: evidently, atmospheric $\mathrm{CO}_{2}$ concentrations changed in 
a)
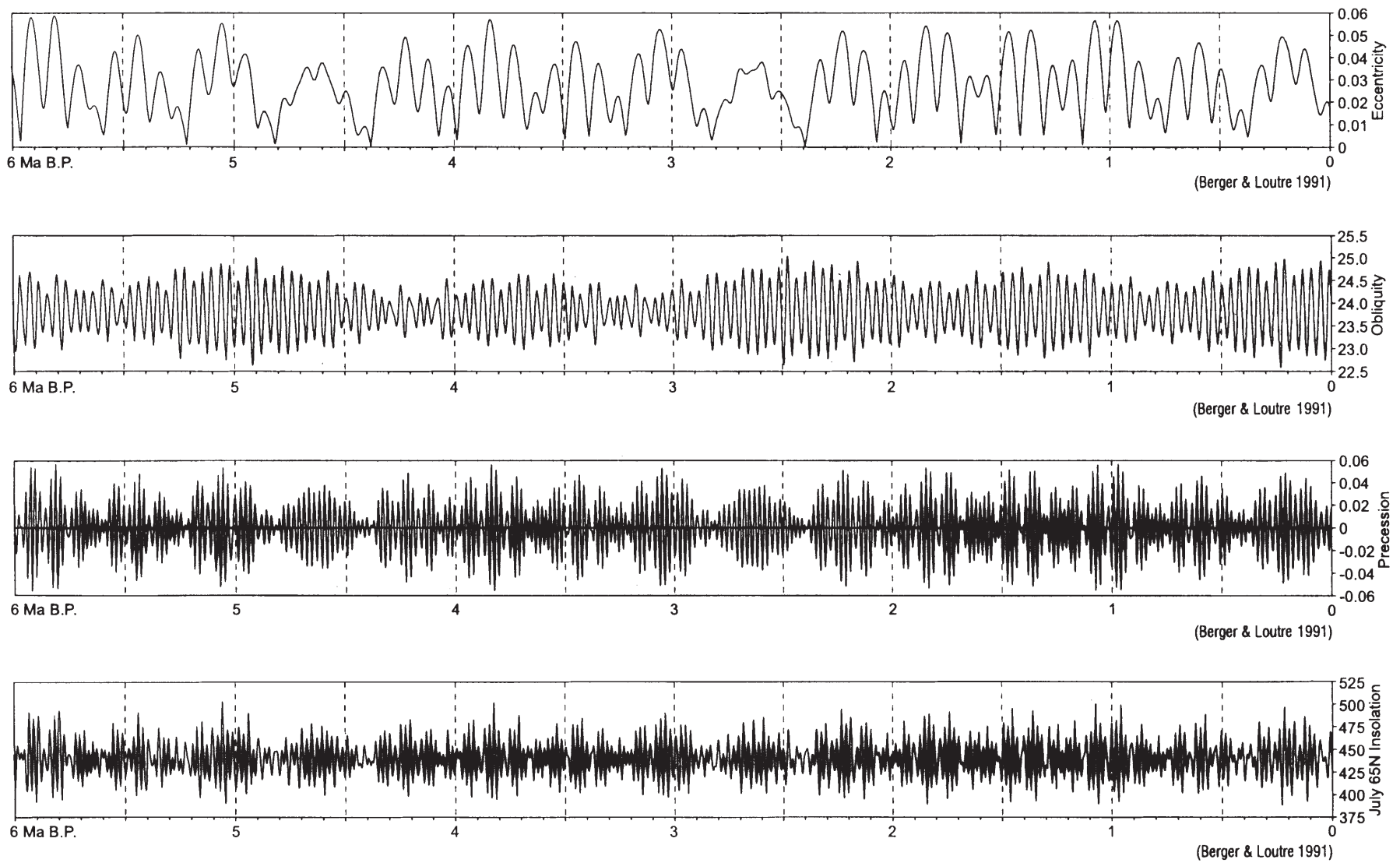

b) 6

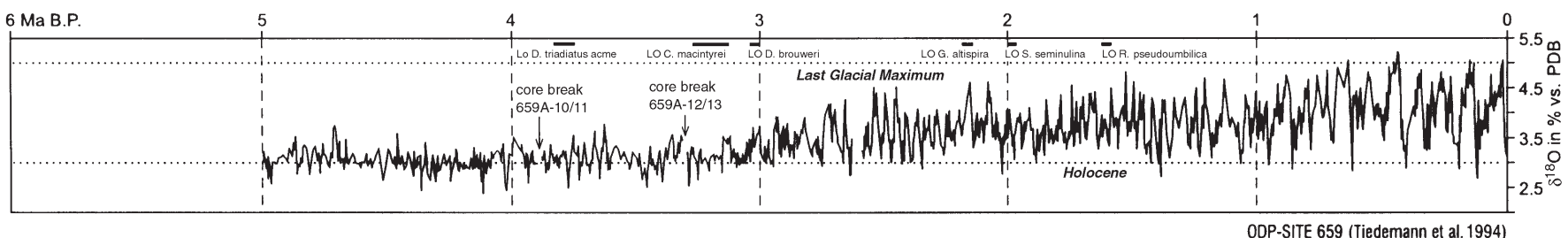

c)

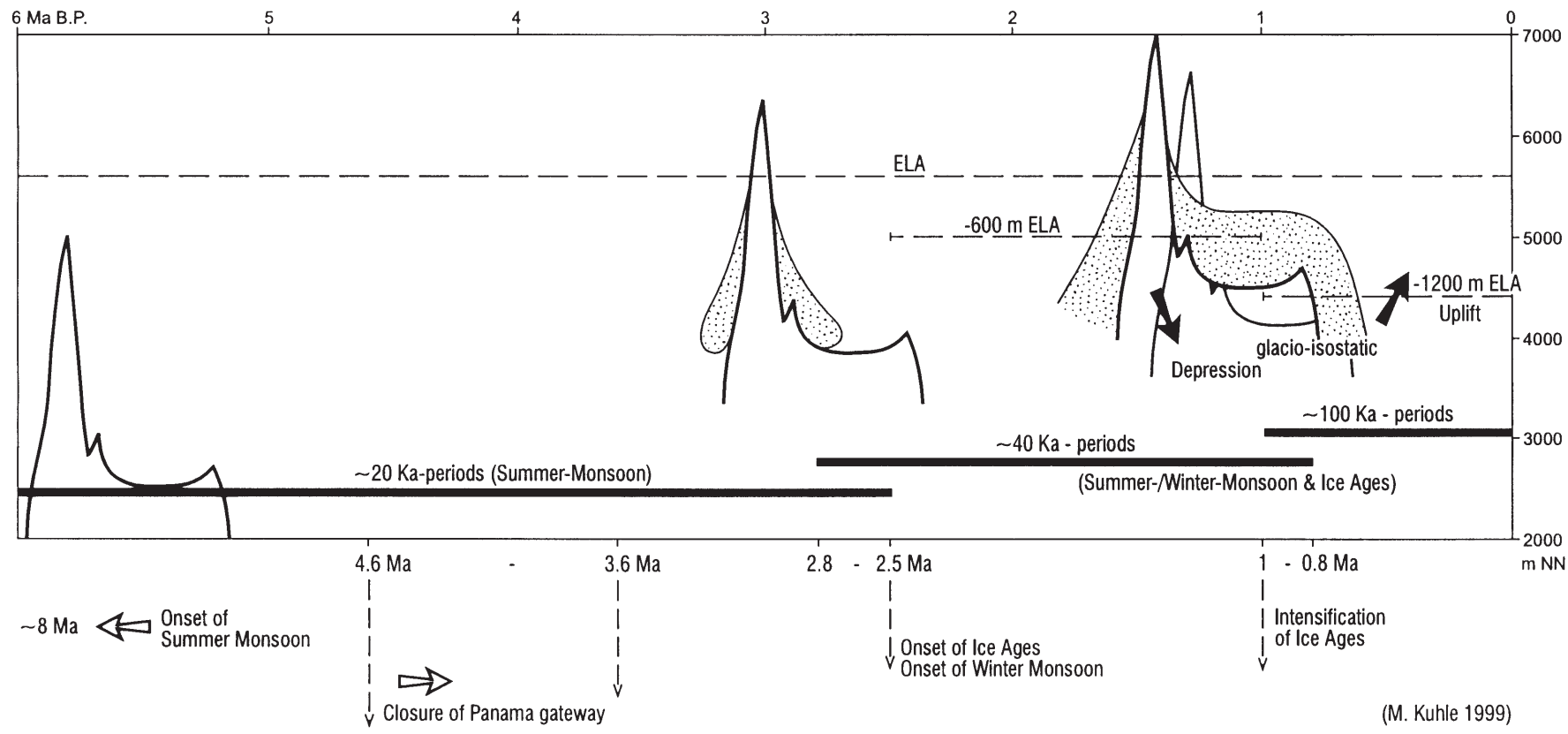


the wake of glacial-interglacial transitions, rather than promoting them.

The hypothesis that the closure of the Panamanian seaway and the resulting North Atlantic deep water formation were responsible for the onset of the ice ages (Haug \& Tiedemann 1998) is still inconclusive. Closure occurred 4.6 to $3.6 \mathrm{Ma}$ ago, i.e. $1 \mathrm{Ma}$ too soon. The argument that increasing obliquity amplitudes between 3.1 and 2.5 Ma BP caused the ice to build up contradicts the fact that the decrease in obliquity amplitudes between 1 and 0.8 Ma does not coincide with ice retreat; on the contrary, it corresponds in time with an intensification of global glaciation (Fig. 1a,b).

Long-term global climatic changes may also have been caused by Cenozoic plateau uplift (especially of the Himalaya-Tibetan and the North American plateaux), inducing a change of zonal wind and precipitation patterns and a steepening of the climatic south-north gradient (Ruddiman \& Kutzbach 1992). However, uplift of the Tibetan plateau started $20 \mathrm{Ma}$ BP ago (Harrison et al. 1992, Copeland 1997) and, as the onset of the summer monsoon suggests, it began to act as a climate-effective barrier some $8 \mathrm{Ma}$ ago (Prell \& Kutzbach 1992, Tiedemann et al. 1994, De Menocal 1995) - too early for the start of the ice ages.

\section{TIBETAN ICE SHEET AS AN ICE AGE TRIGGER}

It has been shown that the Tibetan plateau produces effects on wind patterns similar to those observed at the present time when average elevations of 2000 to $2500 \mathrm{~m}$ are attained (Manabe \& Broccoli 1985, Prell \& Kutzbach 1992). Today, however, the 2.6 million $\mathrm{km}^{2}$ plateau averages $4600 \mathrm{~m}$. In the course of this uplift from 2000 to $4600 \mathrm{~m}$, the plateau surface must have reached and crossed significant climatic thresholds. Such an event at the Tertiary-Quaternary transition must have had a dramatic impact on the global climate. At elevations of
4000 to $4300 \mathrm{~m}$ a seasonal winter snow cover and small glaciers would have formed; from $\sim 4600$ m onwards (its present height), the plateau would have entered a climatic zone where even slight temperature declines $\left(2\right.$ to $3^{\circ} \mathrm{C}$ ) could lead to an extensive ice sheet.

The presence of such a 2.4 million $\mathrm{km}^{2}$ ice sheet on the Tibetan plateau during the Last Glacial Maximum (LGM) has since been demonstrated by our studies of glacial landforms (Kuhle 1982, 1987, 1988, 1990, 1991, $1994,1995,1997,1998,1999)$ on the plateau and in the neighbouring mountain ranges of Kunlun, Qilian Shan, Karakorum and the Himalaya. In addition, dates of lake sediments on the central plateau have now confirmed the existence and time scale of this glaciation. The lakes in the area of the former ice sheet are all younger than $13000 \mathrm{yr}$ old because they developed only after the glaciers had melted (Kashiwaya et al. 1991, Van Campo \& Gasse 1993, Avouac et al. 1996, Gasse et al. 1996). By contrast, lakes in nearby, nonglaciated areas such as the Qaidam basin and the Gobi Desert display continuous sediment records going back more than 40000 yr (Chen \& Bowler 1986, Pachur \& Wünnemann 1995, Rhodes et al. 1996, Wünnemann \& Pachur 1998).

At subtropical latitudes and high altitudes, insolation levels on the Tibetan plateau are close to the solar constant (Kuhle \& Jacobsen 1988) and are therefore 4 times higher than in the areas formerly occupied by the Nordic ice sheets (Fig. 2). An ice-free plateau surface absorbs $80 \%$ of the incoming solar radiation and converts it into longwave radiation; it thus contributes substantially to the warming of the Earth's atmosphere. Our measurements have shown that snow-covered glaciers directly reflect 75 to $95 \%$ of the insolation, which is therefore lost to the global heat balance (Kuhle \& Jacobsen 1988). Calculations indicate that during the LGM as much as $32 \%$ of the albedo-induced energy loss of the Earth's atmosphere was due to the ice sheet of the Tibetan plateau (Biele-

Fig. 1. (a) Astronomical parameters of the earth's orbit and rotation and corresponding insolation values for $65^{\circ} \mathrm{N}$ for the last 6 million yr according to Berger \& Loutre (1991).

(b) Benthic oxygen isotope records from Ocean Drilling Program Site 659 according to Tiedemann et al. (1994). The fluctuations in the $\delta^{18} \mathrm{O}$ content of the foraminifera (vs PeeDee belemnite) reflect the fluctuations of the global ice volume, with high values corresponding to the glacials and low values to the interglacials. Neither the beginning nor the intensification of the Quaternary glaciation period is correlated with the insolation in (a).

(c) Synopsis of the uplift and glaciation of the Tibetan plateau in their relation to other geoecological events. A comparison between (a) and (b) shows that an additional factor apart from orbital variations is required to explain both the start of the ice ages about 2.8 Ma and their increasing intensity from $1 \mathrm{Ma}$ onwards. The closure of the Panama gateway occurred too early to be the terrestrial cause. The uplift of the Tibetan plateau, as far as it can be reconstructed from the onset of the summer and winter monsoons, and, derived from this, the begin of an autochthonous glaciation of Tibet from $2.5 \mathrm{Ma}$ BP onwards, were synchronous with the onset of the global ice ages. Evidence that variations of the summer and winter monsoon intensity documented by marine dust flux records and loess-palaeosol sequences on the Chinese loess plateau occurred in phase not with the insolation variation but with glacial-interglacial cycles (40 ka and $\sim 100 \mathrm{ka}$ periods) is a strong pointer to the existence of a Tibetan glaciation. Gradual uplift of the Tibetan Plateau towards the ELA (equilibrium line) level enabled an ice sheet of 2.4 million $\mathrm{km}^{2}$ to grow from $\sim 1 \mathrm{Ma}$ $\mathrm{BP}$ onwards; the resulting cooling effect permitted a maximum expansion of the Nordic lowland ice sheets ( $-1200 \mathrm{~m}$ ELA). The subsequent glacio-isostatic depression, deglaciation and following rebound of the plateau were responsible for the occurrence and duration of interglacial-glacial cycles ( 100 ka periods) 


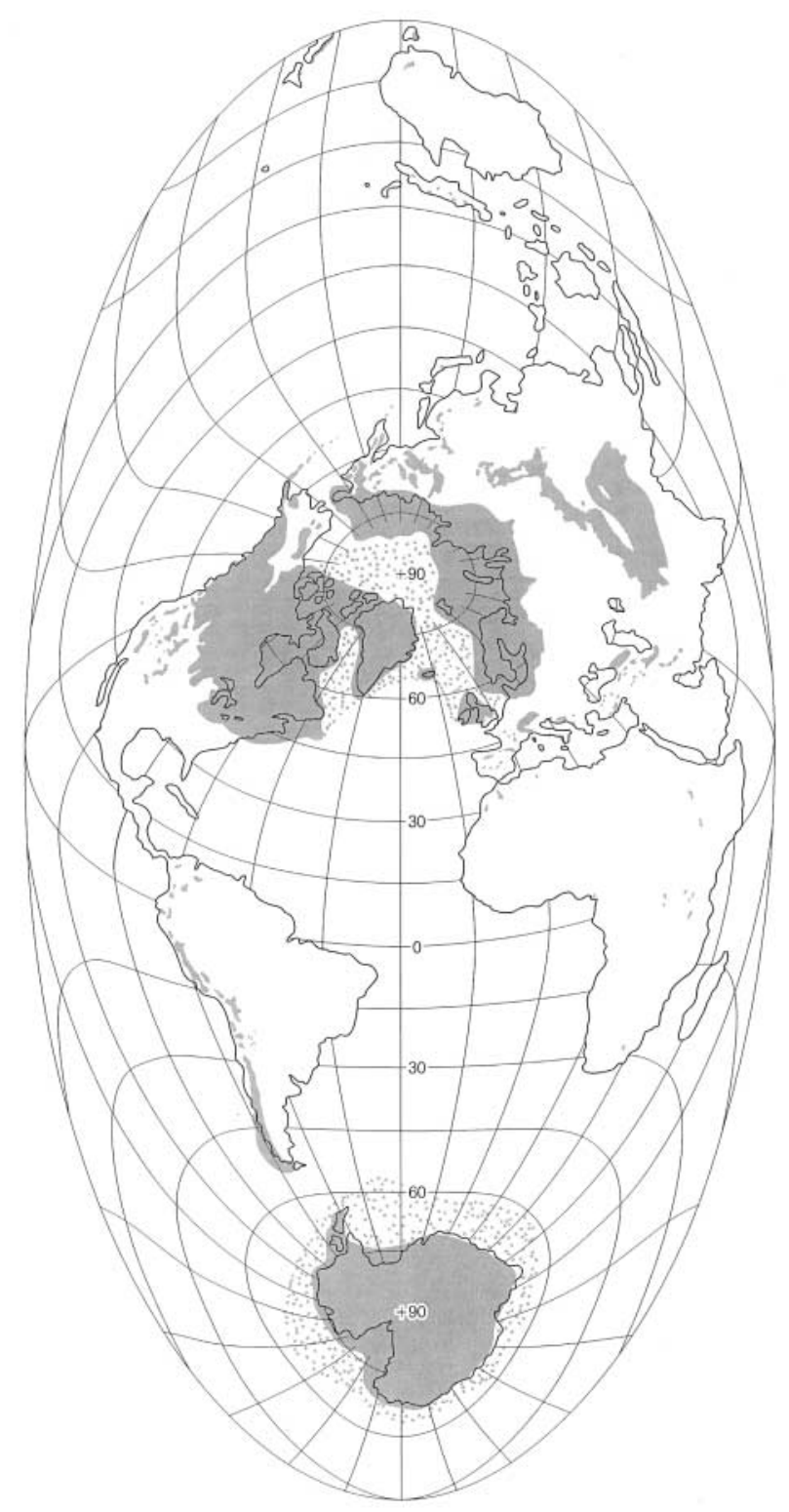

Fig. 2. Maximum extent of glaciated areas during the Last Glacial Maximum (LGM), based on an equal-area projection. Continental ice is indicated by a dense signature, marine ice by a sparse one. In comparison with the near-pole, lowland ice sheets, the 2.4 million $\mathrm{km}^{2}$ Tibetan ice sheet is remarkable for its unique, extremely insolation-favoured, subtropical location with an average surface elevation of 6000 masl. The influence of a Tibetan glaciation is more than 4 times higher than that of a northern lowland glaciation of the same size, i.e. its albedo effect equals that of a $\sim 10$ million $\mathrm{km}^{2}$ northern ice sheet. Based on Broecker \& Denton (1990), modified after Kuhle (1982, 1987, 1988, 1990, 1991, 1994, 1995, 1997, 1998, 1999)

feld 1997). This effect must have been a strong promoter of ice build-up on a global scale.

But the consequences are even more far-reaching. Under present conditions, summer warming of the
Tibetan plateau leads to areas of low surface pressure and hence to a marked atmospheric pressure gradient in relation to the relatively cold adjacent oceans. Strong winds are the result: the East Asian and the Indian summer monsoons (Findlater 1974). The pattern is reversed in winter, when the high albedo of the plateau's winter snow cover leads to cold-induced high surface pressure and thus to a compensatory flow of air to the low surface pressure areas over the now relatively warm oceans, i.e. the winter monsoon circulation (Flohn 1981, Ding et al. 1995, Xiao et al. 1995). Inevitably, the existence of a perennial Tibetan ice sheet must have modified this seasonally alternating large-scale pattern of monsoonal circulation. Whereas the summer monsoon would have been either weaker or non-existent (Sirocko et al. 1993), the winter monsoon must have been much stronger. Data are now available to document that these climatic-ecological effects did indeed occur. Deep-sea cores from the Arabian Sea allow the reconstruction of changes in the upwelling system off Arabia due to variations in strength of the SW Indian monsoon circulation. For the last $500000 \mathrm{yr}$ the data show that the summer monsoon was substantially weaker during the glacial phases, but the winter monsoon was stronger (Anderson \& Prell 1993, Emeis et al. 1995). High-resolution loesspaleosol sequences from China spanning the last 2.5 Ma permit a reconstruction of the intensity fluctuations of the East Asian summer monsoon and supply further confirmation that the summer monsoon was dramatically weaker during glacial times (Rutter \& Ding 1993). For the East Asian winter monsoon, however, the same sequences record a marked increase in intensity during glacial phases (Ding et al. 1995, Xiao et al. 1995). Both marine and terrestrial sediment records document a highly significant correlation between variations in global ice volumes and corresponding counterfluctuations of monsoon circulation throughout the entire ice age era.

\section{CORRELATION BETWEEN TIBETAN UPLIFT AND THE ICE AGE}

These results all confirm our glaciogeological findings: Tibet was indeed covered by an ice sheet during the LGM. In addition, the monsoon chronology reveals the start of the Tibetan plateau's impact on the climate (Fig. 1c). For the summer monsoon to occur, a plateau elevation of 2000 to $2500 \mathrm{~m}$ is required, which was attained around 8 Ma BP (Manabe \& Broccoli 1985, Quade et al. 1989, Prell \& Kutzbach 1992, Tiedemann et al. 1994). The winter monsoon additionally needs the albedo effect of seasonal snow cover (Flohn 1981, Ding et al. 1995, Xiao et al. 1995), requiring plateau 
elevations of 4000 to $4300 \mathrm{~m}$. The remains of a widespread Hipparion fauna in Middle Pliocene sediments of central Tibet are indicators of a warm-tropical steppe climate and show that the altitude of the winter snow zone had not yet been reached at this time (Chen 1981, Ji et al. 1981). Only from 2.5 Ma BP onwards did sediment begin to accumulate on the loess plateau of China, thus recording the onset of winter monsoon circulation (Kukla \& An 1989, An et al. 1990, Ding et al. 1992). As a result of the albedo of a winter snow cover at high subtropical insolation levels, the Tibetan plateau was, for the first time, an effective influence on the absolute heat balance of the Earth, at the same time as the Nordic ice sheets began to expand. Because its elevation was lower than it is today, the plateau had only a 25 to $50 \%$ ice cover at most, even during cold phases. Sensitivity experiments conducted by Marsiat (1994) have shown that under conditions of a reduced glaciation of Tibet the Nordic lowland glaciers also remained rudimentary. This correlates with marine $\delta^{18} \mathrm{O}$ records according to which global ice volumes between 2.5 and $1 \mathrm{Ma}$ BP were only half those during the late Pleistocene (Shackleton et al. 1988, Morley \& Dworetsky 1991, Tiedemann et al. 1994). Glaciation of the Tibetan plateau could only reach its proven LGM extension of 2.4 million $\mathrm{km}^{2}$ when today's average elevation of at least $4600 \mathrm{~m}$ had been attained, i.e. from $~ 1 \mathrm{Ma}$ BP onwards, then inducing maximum global ice volumes. Interglacials occurred only when glacio-isostatic mechanisms caused the plateau areas to subside under the weight of a maximum ice thickness of $2.5 \mathrm{~km}$ (Kuhle 1995), thus enabling a complete deglaciation in phases of positive radiation anomalies.

Tibet's climatic impact first became effective when uplift raised the plateau to the level of the seasonal snowline from $\sim 2.5 \mathrm{Ma}$ BP onwards, and subsequently to the level of maximum glaciation starting at $\sim 1 \mathrm{Ma}$ BP. The progressive glaciation of the Tibetan plateau may thus have been the decisive terrestrial factor causing orbital variations to translate into global ice ages.

\section{PROBLEMS AND POSSIBLE SOLUTIONS}

Glacio-isostatic subsidence of the Tibetan plateau under ice pressure is a prerequisite for the occurrence of interglacial stages. The high uplift rates of $12 \mathrm{~mm}$ $\mathrm{yr}^{-1}$ measured in the region of the Tibetan plateau (Hsu et al. 1998) may be a first indication of glacioisostatic recovery. The author's own observations of moraine deposits on the northern slope of Shisha Pangma, in the border area between the Himalayas and the Tibetan plateau, point in the same direction (Kuhle 1988). These extensive pedestal moraines were left by the ice during the late Last Glacial. Since then, small local plateau glaciers have formed on the moraine surfaces, which can only be explained by strong glacio-isostatic uplift in the meantime, thus raising the plateau closer to the local ELA (equilibrium line).

Kaufmann \& Lambeck (1997, 2000 unpubl.) have shown that, on the basis of secular changes in geoid anomaly and free-air gravity anomaly, it is possible to distinguish the amount of glacio-isostatic uplift from uplift caused by tectonic movements. The predicted effects of the melting of an up to $2 \mathrm{~km}$ thick ice sheet on the Tibetan plateau are so profound that the current satellite missions CHAMP and GRACE would be able to identify them.

A further issue is the extent of the influence of the Tibetan ice sheet on the heat balance of the atmosphere and whether this was marked enough to have a decisive initial impact on the pattern of global ice ages. Only modeling results can provide an answer.

According to our theory the formation of the Nordic lowland glaciers depends on the cooling effect of a high-altitude Tibetan ice sheet, i.e. on a global scale the Tibetan plateau has to be most likely to develop an ice sheet and this has to form in advance of all other areas when temperatures start to fall. Using an atmospheric general circulation model (GCM), Verbitsky \& Oglesby (1992) studied the evolution of ice sheets in relation to the atmospheric $\mathrm{CO}_{2}$ concentration (i.e. temperature change) using a computed 'glaciation sensitivity' index. Their results showed that Tibet and Siberia were more likely to develop an ice sheet than Canada or Fenno-Scandinavia.

Similar conclusions were drawn by Marsiat (1994), who used a 3D climate model to simulate global ice growth generated by temperature changes caused by orbital variations. Here too, the first large ice sheet formed on the Tibetan plateau, followed by Siberia (in contrast to Verbitsky \& Oglesby, Marsiat saw a strong glaciation tendency in Alaska too). Both models thus confirm our hypothesis that the Tibetan ice sheet played a foremost role in terms of time.

The latest modeling results presented by Kutzbach et al. (1998) are in agreeance with the above. However, these climate and biome simulations carried out using the Community Climate Model, Version 1 (CCM1), do not investigate the pattern of ice build-up but are based on the reconstructed glaciation conditions described in CLIMAP Project Members (1981), i.e. the Tibetan plateau is assumed to be non-glaciated. As model results show, there are still 'small areas of permanent snow-cover over non-glaciated areas of western Canada-Alaska, northern Eurasia between the Eastern Siberian and Western Eurasian ice sheets and over Tibet at $21 \mathrm{ka}$. This result indicates that the model would develop a larger area of glaciated land than 
actually appeared to have been present at $21 \mathrm{ka}$. The simulation of permanent snow cover over Tibet contributed to the reduction of the Asian monsoon at 21 ka.' (Kutzbach et al. 1998, p. 496).

That a Tibetan ice sheet not only influenced the monsoon but also had a global impact was demonstrated by a sensitivity experiment conducted by Marsiat (1994). By reducing the global albedo of snowcovered mountain areas, Marsiat attempted to prevent what he considered to be the unrealistic formation of ice sheets on the Tibetan plateau and the Rocky Mountains: 'although the mountainous areas were covered by ice after some period, the perturbation occurring at the beginning of the glacial cycle influences the remainder of the simulation, showing lower ice volumes during the entire glacial cycle.' This suggests that the albedo effect of the Tibetan ice sheet has a global impact.

In order to investigate this impact in greater depth, it is appropriate to use sensitivity experiments with circulation models that consider the Tibetan ice sheet to be a realistic possibility rather than a simulation error. It would make sense to place alternative simulations side by side, showing, on the one hand, the climatic effects of a glaciated Tibetan plateau-as reconstructed by the author on the basis of his empirical fieldwork - and, on the other, simulations based on the old view (von Wissmann 1959) of a non- or only slightly glaciated plateau, which is still being advocated by Derbyshire et al. (1991), among others. Sensitivity experiments with atmospheric circulation models could also be used to quantify the differential influence of the albedo of the various ice sheets on the global cooling balance.

\section{LITERATURE CITED}

An ZS, Liu TS, Lu YC, Porter SC, Kukla G, Wu XH, Hua YM (1990) The long-term paleomonsoon variation recorded by the loess-paleosol sequence in central China. Quat Int 7/8: 91-95

Anderson DM, Prell WL (1993) A 300 KYR record of upwelling off Oman during the late Quaternary: evidence of the Asian southwest monsoon. Paleoceanography 8:193-208

Avouac JPh, Dobremez JF, Bourjot L (1996) Palaeoclimatic interpretation of a topographic profile across middle Holocene regressive shorelines of Longmu Co (Western Tibet). Palaeogeogr Palaeoclimatol Palaeoecol 120:93-104

Berger A, Loutre MF (1991) Insolation values for the climate of the last 10 million years. Quat Sci Rev 10:297-317

Berger A, Li XS, Loutre MF (1999) Modelling northern hemisphere ice volume over the last 3 Ma. Quat Sci Rev 18: $1-11$

Bielefeld B (1997) Investigation into albedo-controlled energy loss during the last glaciation. GeoJournal 42(2-3), Tibet and High Asia IV, Kuhle M (ed), p 329-336

Broecker WS (1995) Chaotic climate. Sci Am 11:44-50

Broecker WS, Denton GH (1990) What drives glacial cycles? Sci Am 1:48-56
Chen K, Bowler JM (1986) Late Pleistocene evolution of salt lakes in the Qaidam basin, Qinghai province, China. Palaeogeogr Palaeoclimatol Palaeoecol 54:87-104

Chen WY (1981) Natural environment of the Pliocene basin in Gyirong, Xizang. In: Geological and ecological studies of Qinghai-Xizang Plateau, Vol 1. Science Press, Beijing, p 343-352

CLIMAP Project Members (1981) Seasonal reconstructions of the earth's surface at the last glacial maximum. Geol Soc Am Map Chart Ser MC-36

Copeland P (1997) The when and where of the growth of the Himalaya and the Tibetan Plateau. In: WF Ruddiman (ed) Tectonic uplift and climate change. Plenum Press, New York, p 20-41

DeMenocal PB (1995) Plio-Pleistocene African climate. Science 270:53-59

Derbyshire E, Shi Y, Li J, Zheng B, Li S, Wang J (1991) Quaternary glaciation of Tibet: the geological evidence. Quat Sci Rev 10:485-510

Ding Z, Rutter N, Han J, Liu T (1992) A coupled environmental system formed at about 2.5 Ma in East Asia. Palaeogeogr Palaeoclimatol Palaeoecol 94:223-242

Ding Z, Liu T, Rutter N, Zhiwei Y, Zhengtang G, Rixiang Z (1995) Ice-volume forcing of East Asian winter monsoon variations in the past 800,000 years. Quat Res 44:149-159

Emeis KCh, Anderson DM, Doose H, Kroon D, Schulz-Bull D (1995) Sea-surface temperatures and the history of monsoon upwelling in the Northwest Arabian Sea during the last 500, 000 years. Quat Res 43:355-361

Findlater J (1974) The low-level cross-equatorial air current of the western Indian Ocean during the Northern Summer. Weather 29:411-416

Fischer H, Wahlen M, Smith J, Mastroianni D, Deck B (1999) Ice core records of atmospheric $\mathrm{CO}_{2}$ around the last three glacial terminations. Science 283:1712-1714

Flohn H (1981) The elevated heat source of the Tibetan highlands and its role for the large scale atmospheric circulation. In: Geological and ecological studies of the QinghaiXizang Plateau, Vol 2. Science Press, Beijing, and Gordon and Breach, New York, p 1463-1469

Gasse F, Fontes JCh, Van Campo E, Wei K (1996) Holocene environmental changes in Bangong Co basin (Western Tibet). Part 4: Discussion and conclusions. Palaeogeogr Palaeoclimatol Palaeoecol 120:79-92

Harrison TM, Copeland P, Kidd WSF, An Y (1992) Raising Tibet. Science 255:1663-1670

Haug GH, Tiedemann R (1998) Effect of the formation of the Isthmus of Panama on Atlantic Ocean thermohaline circulation. Nature 393:673-676

Hays JD, Imbrie J, Shackleton NJ (1976) Variations in the earth's orbit: pacemaker of the ice ages. Science 194: 1121-1132

Hsu H, Zhang C, Wang Y (1998) Study on crustal movements of Tibetan plateau and its mechanism by geodetic methods. In: Int Symp Qinghai-Tibet Plateau (Xining, China):4

Ji HX, Huang WP, Chen WY, Wu QQ, Zheng SH (1981) The discovery of the Hipparion faunas in Tibet and its significance on the problem of the uplift of the Plateau. In: Studies on the period, amplitude and type of the uplift of the Tibetan Plateau. Science Press, Beijing, p 19-25

Kashiwaya K, Yaskawa K, Yuan B, Liu J, Gu Z, Cong S, Masuzawa T (1991) Paleohydrological processes in SilingCo (Lake) in the Qing-Zang (Tibetan) Plateau based on the physical properties of its bottom sediments. Geophys Res Lett 18(9):1779-1781

Kaufmann G, Lambeck K (1997) Implications of Late Pleistocene glaciation of the Tibetan Plateau for present-day 
uplift rates and gravity anomalies. Quat Res 48:267-279

Kuhle M (1982) Der Dhaulagiri- und Annapurna-Himalaya. Z Geomorphol Suppl 41, Vol I, p 1-229, and Vol II, Figs 1-184

Kuhle M (1987) Subtropical mountain- and highland-glaciation as ice age triggers and the waning of the glacial periods in the Pleistocene. GeoJournal 14(4):393-421

Kuhle M (1988) Geomorphological findings on the build-up of Pleistocene glaciation in southern Tibet and on the problem of inland ice. Results of the Shisha Pangma and Mt. Everest Expedition 1984. GeoJournal 17(4), Tibet and High Asia, Results of the Sino-German Joint Expeditions (I), Kuhle M, Wang W (eds), p 457-511

Kuhle M (1990) New data on the Pleistocene glacial cover of the southern border of Tibet: the glaciation of the Kangchendzönga Massif (8585 m, E-Himalaya). GeoJournal 20(4):415-421

Kuhle M (1991) Observations supporting the Pleistocene inland glaciation of High Asia. GeoJournal 25(2-3), Tibet and High Asia, Results of the Sino-German Joint Expeditions (II), Kuhle M, Xu D (eds), p 133-231

Kuhle M (1994) Present and Pleistocene glaciation on the north-western margin of Tibet between the Karakoram Main Ridge and the Tarim Basin supporting the evidence of a Pleistocene inland glaciation in Tibet. GeoJournal 33(2-3), Tibet and High Asia, Results of the Sino-German Joint Expeditions (III), Kuhle M (ed), p 133-272

Kuhle M (1995) Glacial isostatic uplift of Tibet as a consequence of a former ice sheet. GeoJournal 37(4):431-449

Kuhle M (1997) New findings concerning the Ice Age (LGM) glacier cover of the East Pamir, of the Nanga Parbat up to the Central Himalaya and of Tibet, as well as the age of the Tibetan inland ice. GeoJournal 42(2-3), Tibet and High Asia IV, Kuhle M (ed), p 87-257

Kuhle M (1998) Reconstruction of the 2.4 million $\mathrm{km}^{2}$ Late Pleistocene ice sheet on the Tibetan Plateau and its impact on the global climate. Quat Int 45/46:71-108 (additional figures in 47/48:173-182)

Kuhle M (1999) Reconstruction of an approximately complete Quaternary Tibetan inland glaciation between the Mt. Everest and Cho Oyu massifs and the Aksai Chin. A new glaciogeomorphological SE-NW diagonal profile through Tibet and its consequences for the glacial isostasy and ice age cycle. GeoJournal 47(1-2), Tibet and High Asia V, Kuhle M (ed), p 3-276

Kuhle M, Jacobsen JP (1988) On the geoecology of Southern Tibet. GeoJournal 17(4), Tibet and High Asia, Results of the Sino German Joint Expeditions (I), Kuhle M, Wang W (eds), p 597-613

Kukla G, An ZS (1989) Loess stratigraphy in central China. Palaeogeogr Palaeoclimatol Palaeoecol 72:203-225

Kutzbach J, Gallimore R, Harrison S, Behling P, Selin R, Laarif F (1998) Climate and biome simulations for the past 21,000 years. Quat Sci Rev 17:473-506

Manabe S, Broccoli AJ (1985) The influence of continental ice sheets on the climate of an ice age. J Geophys Res 90: $2167-2190$

Marsiat I (1994) Simulation of the northern hemisphere continental ice sheets over the last glacial-interglacial cycle: experiments with a latitude-longitude vertically integrated ice sheet model coupled to a zonally averaged climate model. Palaeoclimates 1:59-98

Morley JJ, Dworetzky BA (1991) Evolving Pliocene-Pleistocene climate: a North Pacific perspective. Quat Sci Rev

Editorial responsibility: Hans von Storch,

Geesthacht, Germany
10:225-237

Mudelsee M (2001) The phase relations among atmospheric $\mathrm{CO}_{2}$ content, temperature and global ice volume over the past $420 \mathrm{ka}$. Quat Sci Rev 20:583-589

Pachur HJ, Wünnemann B (1995) Lake evolution in the Tengger Desert, northwestern China, during the last 40,000 years. Quat Res 44:171-180

Pagani M, Freeman KH, Arthur MA (1999) Late Miocene atmospheric $\mathrm{CO}_{2}$ concentrations and the expansion of $\mathrm{C} 4$ grasses. Science 285:876-879

Pearson PN, Palmer MR (1999) Middle Eocene seawater pH and atmospheric carbon dioxide concentrations. Science 284:1824-1826

Prell WL, Kutzbach JE (1992) Sensitivity of the Indian monsoon to forcing parameters and implications for its evolution. Nature 360:647-652

Quade J, Cerling TE, Bowman JR (1989) Development of Asian monsoon revealed by marked ecological shift during the latest Miocene in northern Pakistan. Nature 342: 163-166

Rhodes TE, Gasse F, Lin Ruifen, Fontes JCh, and 7 others (1996) A Late Pleistocene- Holocene lacustrine record from Lake Manas, Zunggar (Northern Xinjiang, Western China). Palaeogeogr Palaeoclimatol Palaeoecol 120: 105-118

Ruddiman WF, Kutzbach JE (1991) Plateau uplift and climatic change. Sci Am 3:42-50

Ruddiman WF, Raymo ME, Prell WL, Kutzbach JE (1997) The uplift-climate connection: a synthesis. In: Ruddiman WF (ed) Tectonic uplift and climate change. Plenum Press, New York, p 471-515

Rutter N, Ding Z (1993) Paleoclimates and monsoon variations interpreted from micromorphogenic features of the Baoji Paleosols, China. Quat Sci Rev 12:853-862

Shackleton NJ, Imbrie FRS, Pisias NG (1988) The evolution of oxygen-isotope variability in the North Atlantic over the past three million years. Phil Trans R Soc Lond B 318: $679-688$

Sirocko F, Sarnthein M, Erlenkeuser H (1993) Century-scale events in monsoonal climate over the past 24,000 years. Nature 364:322-324

Tiedemann R, Sarnthein M, Shackleton NJ (1994) Astronomic timescale for the Pliocene Atlantic $\mathrm{O}^{18}$ and dust flux records of Ocean Drilling Program site 659. Paleoceanography 9(4):619-638

Van Campo E, Gasse F (1993) Pollen- and diatom-inferred climatic and hydrological changes in Sumxi Co Basin (Western Tibet) since 13,000 yr BP. Quat Res 39:300-313

Verbitsky MY, Oglesby RJ (1992) The effect of atmospheric carbon dioxide concentration on continental glaciation of the northern hemisphere. J Geophys Res 97(D5):5895-5909

von Wissmann H (1959) Die heutige Vergletscherung und Schneegrenze in Hochasien mit Hinweisen auf die Vergletscherung der letzten Eiszeit. Akad Dtsch Wiss U Lit Abh D Math-Natwiss Kl 14:1103-1407

Wünnemann B, Pachur HJ, Li J, Zhang H (1998) Chronologie der pleistozänen und holozänen Seespiegelschwankungen des Gaxun Nur/Sogo Nur und Baijian $\mathrm{Hu}$, Innere Mongolei, Nordwestchina. Petermanns Geogr Mitt 142(3+4):191-206

Xiao J, Porter SC, An Z, Kumai H, Yoshikawa S (1995) Grain size of quartz as an indicator of winter monsoon strength on the loess plateau of central China during the last 130, 000 yr. Quat Res 43:22-29

Submitted: November 27, 2000; Accepted: July 10, 2001

Proofs received from author(s): January 2, 2002 